\title{
Pengetahuan Ibu Menyusui Pasca Edukasi Tentang Asi Eksklusif
}

\author{
Afrizal Rifa'i ${ }^{*}$, Sri Lestari Dwi Astuti' ${ }^{2}$, Yuyun Setyorini ${ }^{3}$ \\ 1,2,3 Jurusan Keperawatan, Poltekkes Kemenkes Surakarta \\ *Email: Afrizalpesagi1234@gmail.com
}

\begin{abstract}
Background: Exclusive breastfeeding has important role in ensuring adequate nutrition, stunting prevention, and child development. The success rate of exclusive breastfeeding in the World is only (38\%), Indonesia (65.1\%), Central Java (78.5\%) and the working area of Sibela Local Government Clinic of Surakarta (85.4\%). Maternal's knowledge level is part of the determinants of success rates in exclusive breastfeeding. Health education is efforts used to increase maternal knowledge about exclusive breastfeeding. Methods: This research is Pre Experiment with One Group Pre-Post Test. The methode of collecting of data is accidental sampling with questionnaire who containing 20 questions. The comparative hypothesis test used Wilcoxon test. Results: from 42 respondents, 22 (52.4\%) had high school education, 21 (50\%) were housewives, 24 (57.1\%) according to the range of early adulthood (2635 years) and 31 (73.8\%) had got education about exclusive breastfeeding from health workers. The comparative hypothesis test results show a significance 0,00 (p value <0.05). Conclusion: There is an effect of health education about exclusive breastfeeding on the knowledge of breastfeeding maternal in the Sibela Local Government Clinic of Surakarta.
\end{abstract}

Keywords: breastfeeding maternal, exclusive breastfeeding, health education

\section{PENDAHULUAN}

Pemberian Air Susu Ibu (ASI) merupakan proses yang tidak dapat dilewatkan dalam menjamin kecukupan gizi serta proses tumbuh kembang anak. Berbagai komponen penting dari ASI diantaranya adalah protein, kalori, vitamin, karbohidrat, lemak, dan mineral (Widanti, 2013). World Health Organization (WHO), (2008) dalam Riset Kesehatan Dasar (Riskesdas), (2018) menyebutkan bahwa ASI Eksklusif diberikan dalam enam bulan pertama pasca kelahiran tanpa tambahan cairan atau bahan makanan lain, kecuali obat dan vitamin.

Tahun 2013, KEMENKES RI telah menerbitkan Surat Keputusan (Np.459/Menkes./SK/IV/2004) yang berisikan rekomendasi pemberian ASI ekslusif. Disebutkan bahwa ASI Ekslusif harus didapatkan anak sejak usia 0-6 bulan (Claudia, 2018). Saat ASI eksklusif diberikan kepada anak secara otomatis risiko berbagai penyakit infeksi balita telah diminalisir. Beberapa penyakit yang kerap menyerang balita diantaranya infeksi saluran cerna, saluran nafas bahkan saluran perkemihan. Ketidakcukupan dalam pemberian ASI juga memiliki hubungan erat dengan kejadian malnutrisi. Kondisi tersebut bahkan menjadi pemicu terjadinya balita pendek (stunting) (Infodatin, 2018).

Didunia, tercatat 155 juta balita mengalami stunting setiap tahunnya (Infodatin, 2018). Penelitian Damayanti \& Muniroh, (2016) menyebutkan prevalensi stunting lebih kecil pada balita yang memiliki riwayat pemberian ASI Eksklusif. Sedangkan, prevalensi lebih besar pada balita yang tidak memiliki riwayat pemberian ASI Eksklusif. Hasil penelitian Anjani, (2018) juga menyebutkan stunting lebih kerap terjadi pada kelompok anak (12-35 bulan) yang tidak mendapatkan ASI secara Eksklusif $(51,4 \%)$, sedangkan presentase yang 
mendapat ASI Eksklusif lebih minimal (19\%). Dari kedua penelitian tersebut dapat disimpulkan bahwa pemberian ASI eksklusif memiliki peranan penting dalam mencegah kekurangan gizi pada anak, bahkan stunting.

United Nations Children's Fund (UNICEF) dalam (Asesora et al., 2016) menyebutkan terdapat 132 juta kelahiran bayi pertahunnya di seluruh dunia. Dari jumlah tersebut, tidak lebih dari 51 juta (38\%) bayi yang diberikan ASI secara Eksklusif. Itu berarti bahwa ada 81 juta (62\%) bayi yang tidak diberikan ASI secara eksklusif. Angka tersebut mencerminkan tingkat keberhasilan dalam pemberian ASI Eksklusif yang belum optimal.

Berdasarkan data (Riskesdas, 2018) disebutkan angka keberhasilan pemberian ASI Eksklusif di Indonesia baru mencapai $74,5 \%$ dari total bayi di Indonesia. Profil Anak Indonesia (PAI, 2018) juga menyebutkan angka keberhasilan pemberian ASI Eksklusif di Indonesia baru mencapai $65,16 \%$ dari total bayi di Indonesia. Kedua data tersebut menggambarkan bahwa keberhasilan dalam pemberian ASI di Indonesia belum cukup optimal.

Terdapat banyak faktor yang berpengaruh dalam keberhasilan pemberian ASI secara eksklusif. Dalam penelitian yang dilakukan Pratiwi et al., (2014) disebutkan beberapa hambatan yang kerap terjadi dalam pemberian ASI Eksklusif diantaranya adalah belum optimalnya pengetahuan ibu mengenai pentingnya memberikan ASI Eksklusif, masih beredarnya anggapan bahwa bayi akan kelaparan jika hanya diberi ASI, anggapan bahwa bayi harus diberikan formula agar tidak rewel, keinginan ibu untuk menyusui masih rendah, bahkan masih banyak ibu yang tidak mengetahui teknik memberikan ASI kepada bayi. Hasil penelitian Arifiati, (2017) juga menyebutkan beberapa hal yang berpengaruh dalam keberhasilan menyusui secara eksklusif adalah pekerjaan ibu, tinggi rendahnya pengetahuan ibu, serta dukungan positif yang diberikan oleh keluarga \& tenaga kesehatan. Penelitian Satino \& Setyorini, (2014) juga menyebutkan bahwa tingkat pendidikan ibu merupakan faktor penting dalam mencapai kata 'optimal' dalam memberikan ASI secara eksklusif.

Dari beberapa sumber literatur tersebut, disimpulkan bahwa tinggi atau rendahnya pengetahuan ibu mengenai ASI, memiliki peranan penting terhadap keberhasilan dalam memberikan ASI secara Eksklusif. Hal ini dipertegas kembali melalui penelitian (Kawulur et al., 2015) yang menyimpulkan bahwa terdapat hubungan erat antara tinggi rendahnya pengetahuan Ibu dengan capaian ASI Eksklusif di Malalayang, Manado. Provinsi Jawa Tengah memiliki presentase keberhasilan pemberian ASI Eksklusif sebesar 78,59\% (Riskesdas, 2018). Seluruh kota yang ada di dalamnya, tentu telah memiliki peranan dalam mendukung keberhasilan ASI eksklusif, termasuk Kota Surakarta.

Penulis telah melakukan studi pendahuluan di wilayah kerja UPT Puskesmas Sibela Surakarta. Tercatat 234 kelahiran bayi di wilayah kerjanya dalam kurun waktu 1 Agustus 2018 - 30 Januari 2019. Dari jumlah tersebut hanya 151 $(64,5 \%)$ bayi yang mendapatkan ASI Eksklusif. Pada 1 Februari 2019 - 30 Agustus 2019 tercatat sebanyak 233 kelahiran dengan pemberian ASI Eksklusif sebanyak 199 (85,4\%) bayi. Berdasarkan data tersebut, disimpulkan 
bahwa masih diperlukannya ikhtiar yang lain dalam mencapai kata 'optimal'. Tujuan dari penelitian ini untuk mengetahui pengaruh edukasi tentang menyusui terhadap peningkatan pengetahuan Ibu tentang ASI eksklusif.

\section{METODE PENELITIAN}

Jenis penelitian yang dilakukan oleh peneliti adalah pre experiment dengan satu kelompok pre-post test. Teknik sampling adalah dengan accidental sampling. Penulis telah mengukur tingkat pengetahuan ibu dengan menggunakan kuisioner yang telah diadopsi dari penelitian Tiastuti (2015) dalam (Suprihatin, 2018). Kuisioner yang telah diadopsi terdiri atas 20 soal pilihan ganda dengan rincian: 3 soal untuk mengukur pengetahuan umum tentang ASI Eksklusif; 4 soal tentang kolostrum; 3 soal mengenai manfaat pemberian ASI Eksklusif bagi bayi; 3 soal tentang manfaat memberikan ASI Eksklusif untuk ibu; 4 soal mengenai cara agar berhasil dalam memberikan ASI Eksklusif; dan 3 soal lainnya tentang cara memberikan ASI Eksklusif bagi ibu yang bekerja.

Responden yang ikut berperan dalam penelitian ini merupakan $42 \mathrm{ibu}$ menyusui yang sedang kontrol di UPT Puskesmas Sibela Surakarta. Penelitian dilakukan pada 30 Januari - 03 Februari 2020. Untuk menguji hipotesis komparatif yang telah ditetapkan penulis, maka penulis menggunakan uji wilcoxon.

\section{HASIL PENELITIAN}

Dalam penelitian ini, peneliti telah melakukan persiapan berupa penyiapan media booklet, penguasaan materi, dan menyampaikan materi semaksimal mungkin. Responden dalam penelitian ini memiliki tingkat pendidikan, sosial ekonomi, kepercayaan dan keadaan lingkungan yang berbeda. Waktu untuk mengumpulkan data penelitian adalah pukul 08.00-11.00 WIB, yakni saat responden sedang mengantri di poliklinik UPT Puskesmas Sibela Surakarta.

Hasil dari penelitian terhadap $42 \mathrm{ibu}$ menyusui, didapatkan 22 ibu $(52,5 \%)$ berpendidikan SMA, 21 ibu $(50 \%)$ merupakan Ibu Rumah Tangga (IRT), 24 ibu $(57,1 \%)$ merupakan ibu berkategori dewasa awal (26-35 th) dan 31 ibu $(73,8 \%)$ pernah mendapatkan informasi mengenai ASI Eksklusif melalui petugas kesehatan.

Tabel 1. Hasil Uji Hipotesis Komparatif Wilcoxon tentang Gambaran Peningkatan Pengetahuan Responden Berdasaran Nilai Pre dan Post Test.

\begin{tabular}{lcc}
\hline Perbandingan Nilai & N & Presentase (\%) \\
\hline Post-Test $>$ Pre-Test & 31 & 73,8 \\
Post-Test $=$ Pre-Test & 11 & 26,1 \\
\hline Jumlah & $\mathbf{4 2}$ & $\mathbf{1 0 0}$ \\
\hline Terdapat 31 ibu (73,8\%) yang & post test, sedangkan 11 ibu (26,1\%) tidak \\
memperoleh nilai lebih tinggi pada saat & $\begin{array}{c}\text { mengalami peningkatan nilai. }\end{array}$
\end{tabular}


Tabel 2. Hasil Dari Uji Wilcoxon Tentang Perolehan P-Value dan Peningkatan Rerata Nilai (Pre-Post Test).

\begin{tabular}{llllc}
\hline Komponen & N & Mean & St. Dev & P-Value \\
\hline Pre-test & 42 & 88,45 & 10,678 & \multirow{2}{*}{0,000} \\
Post-test & 42 & 96,90 & 5,174 & \\
\hline Selis & & & 8,45 &
\end{tabular}

Selisih

Ada peningkatan pengetahuan yang bermakna pada ibu menyusui yang telah diberikan pendidikan kesehatan tentang ASI Eksklusif ditandai dengan ( $p$ value $0,000)$ dan peningkatan rerata skor sebesar 8,45 .

\section{PEMBAHASAN}

Hasil penelitian ini menunjukkan 22 responden $(52,4 \%)$ memiliki pendidikan terakhir SMA. Tinggi rendahnya pendidikan seseorang memiliki peranan dalam menentukan pengetahuan (Sriyono, 2015). Hasil ini tidak bertentangan dengan hasil yang ditemukan oleh (Claudia, 2018). Ia menyebutkan mayoritas pendidikan respondennya adalah SMA (52\%). (Notoatmodjo, 2012) menyebutkan bahwa pendidikan mampu untuk mempengaruhi perilaku seseorang. Hal tersebut mampu juga mempengaruhi pola hidup, motivasi diri, kemudahan dalam menerima informasi, bahkan tingkat pengetahuan seseorang (Huda \& Delita, 2016). Dalam penelitian (Kawulur et al., 2015) telah ditarik sebuah kesimpulan bahwa tingkat pengetahuan serta sikap ibu sangat berhubungan dengan perilaku pemberian ASI secara Eksklusif.

Distribusi frekuensi berdasarkan pekerjaan ibu dalam penelitian ini menunjukkan 21 responden $(50 \%)$ merupakan Ibu yang bekerja di rumah. Dengan demikian, mereka memiliki kesempatan yang lebih besar untuk bersama bayi dibandingkan dengan ibu yang bekerja diluar rumah, mereka dapat melakukan pemberian ASI Eksklusif yang $\mathbf{8 , 4 5}$

lebih optimal di rumah. Hal ini sejalan dengan penelitian (Bahriyah, Putri, \& Jaelani, 2017) yang menyebutkan angka keberhasilan ASI Eksklusif lebih dominan pada ibu yang bekerja di rumah dibandingkan dengan ibu yang bekerja di luar rumah. Penelitian (Bahriyah et al., 2017) juga menyebutkan bahwa status pekerjaan ibu memiliki hubungan yang signifikan terhadap keberhasilan ASI Eksklusif.

Rentang usia ibu dalam penelitian ini menunjukkan 24 responden $(57,1 \%)$ masuk ke dalam kategori usia dewasa awal (26-35). Tanoro, (2007) menyebutkan bahwa usia dewasa awal merupakan tahapan usia yang yang sangat berpengaruh terhadap perkembangan kognitif (intelektual) seperti kemampuan dalam memecahkan masalah, mengambil keputusan, daya ingat, perkembangan pola berfikir serta kombinasi antara kematangan dengan pengalaman. Hal ini dipertegas kembali dalam penelitian (Rohani, 2013) yang menyebutkan bahwa usia menjadi faktor yang cukup mendominasi dalam keterampilan ibu merawat bayi. Penelitian Sringati et al, (2016) juga menyebutkan tingkat pengetahuan ibu memiliki peranan penting dalam keberhasilan ASI eksklusif.

Selain memberikan kuisioner tentang pengetahuan ibu mengenai ASI Eksklusif, peneliti juga telah mengaji data demografi responden. Didapatkan hasil bahwa sebagian besar ibu sudah pernah mendapat informasi mengenai ASI Eksklusif. 31 responden $(73,8 \%)$ telah 
menerima informasi melalui tenaga kesehatan tempatnya memeriksakan kesehatan. Hasil tersebut tidak bertentangan dengan pendapat Sudarma dalam Aprilian, (2017) yang menyebutkan salah satu peranan perawat adalah sebagai edukator. Empat tugas perawat sebagai edukator diantaranya: memberikan fasilitas pengajaran kepada pasien, menjelaskan hal yang tidak diketahui pasien, memberikan nasihat dan dukungan terhadap pasien serta memberikan contoh yang baik kepada pasien. Sunaryo, (2016) menyebutkan seseorang yang mendapatkan informasi baru berarti akan menstimulasi fungsi kognitif, afektif, dan psikomotornya yang akan membuat syaraf-syaraf otak berfungsi secara normal.

Akumulasi perolehan nilai dalam penelitian ini menunjukkan nilai post-test (4070) lebih besar dari pre-test (3715). Hasil tersebut berarti bahwa ada peningkatan yang signifikan pada pengetahuan responden. Hasil yang diperoleh tersebut, tidak bertolak belakang dengan pernyataan Merdhika et al, (2014) yang menyebutkan adanya perbedaan tingkat pengetahuan sebelum dan sesudah diberikan edukasi tentang ASI Eksklusif.

Hasil uji hipotesis komparatif (uji wilcoxon) terhadap nilai Pre dan Post Test menunjukkan angka signifikansi sebesar 0,00 ( $p$ value $<0,05$ ) yang mengandung arti ada perbedaan yang cukup bermakna sebelum dan setelah diberi edukasi tentang ASI Eksklusif. (Notoatmodjo, 2010) menyebutkan beberapa hal yang mampu mempengaruhi keberhasilan edukasi kesehatan, yaitu: Faktor penyuluh (persiapan, penguasaan materi, penyampaian materi, dll); Faktor sasaran (tingkat pendidikan, sosial ekonomi, kepercayaan, kondisi lingkungan, dll); dan
Faktor proses dalam pendidikan kesehatan (waktu, tempat, dan jumlah sasaran).

\section{KESIMPULAN DAN SARAN}

Tingkat pengetahuan ibu menyusui meningkat setelah diberikan edukasi kesehatan. Kesimpulan diambil dengan merujuk pada akumulasi skor pre-test sejumlah 3715 poin, sedangkan nilai posttest 4070 poin. Kesimpulan dipertegas dengan hasil uji hipotesis komparatif dengan uji Wilcoxon. Hasil uji menunjukkan signifikansi sebesar 0,00 ( $p$ value $<0,05$ ) yang berarti bahwa terdapat Pengaruh Edukasi Kesehatan Tentang ASI Eksklusif Terhadap Pengetahuan Ibu Menyusui di UPT Puskesmas Sibela Surakarta. Petugas kesehatan perlu menggencarkan edukasi ASI eksklusif untuk mencegah stunting.

\section{DAFTAR RUJUKAN}

Anjani, W. D. (2018). Hubungan Asi Eksklusif dengan Stunting balita (12-35 bulan) di Puskesmas Air Dingin . FK Unand. Diunduh dari: http://scholar.unand.ac.id

Aprilian. (2017). Peran perawat sebagai pemberi edukasi kepada pasien pascaoperasi di RS Umum Bahteramas, Sul-Teng.

Arifiati, N. F. (2017). Peran Tenaga Kesehatan Dalam Pelaksanaan Sdgs\&Quot. National Proceding. IKAKESMADA, 978-979. Diunduh dari: http://eprints.uad.ac.id

Asesora, J., (2016). Una oportunidad para cada niño. In (UNICEF).

Bahriyah, F., Putri, M., \& Jaelani, A. K. (2017). Hubungan pemberian ASI secara eksklusif dengan status pekerjaan ibu di puskesmas sipayug. 
Jurnal Endurance. Diunduh dari: https://doi.org/10.22216/jen.v2i2.169 9

Claudia, U. G. (2018). Gambaran Pengetahuan sebelum dan sesudah penyuluhan ASI Eksklusif menggunakan media leaflet di Puskesmas Parigi. Jakarta.

Damayanti, R. A., \& Muniroh, L. (2016). ASK Eksklusif yang diberikan pada balita stunting dan tidak. 11, 61-69.

Huda, \& Delita. (2016). Moodel pengajaran serta isu metodis juga paradigmatis. Yogyakarta: Pustaka Pelajar.

Infodatin. (2018). Menyusui sebagai Dasar Kehidupan. 1-7. Diunduh dari: www.depkes.go.id

Kawulur, G. F., (2015). Pemberian Air Susu Ibu secara Eksklusif di Manado.

Notoatmodjo, S. (2010). Teori dan pengaplikasian promosi kesehatan, edisi revisi 2010. Jakarta: Rineka Cipta. Diunduh dari: https://doi.org/10.1108/JMTM-032018-0075

Notoatmodjo, S. (2012). Perilaku dalam Kesehatan serta Promkes. Edisi 2012. Jakarta: Rineka Cipta. https://doi.org/10.1111/j.13652648.2010.05450.x

PAI. (2018). Profil Anak Indonesia 2018.

Pratiwi, V. R., (2014). Gagalnya pemberian ASI Eksklusif pada ibu kategori muda. Diunduh dari: http://eprints.undip.ac.id/67092/

RISKESDAS. (2018). Riskesdas 2018. Development.
Rohani, S. (2013). Beberapa Faktor yang Berpengaruh terhadap Keterampilan dan Pengetahuan Ibu Merawat Bayi di Ruang Nifas, kab. Jeneponto. JIKD Vol.3 No.5, 41-50. Diunduh dari:

http://www.ejournal.stikesnh.ac.id

Satino \& Setyorini, Y. (2014). Faktor yang Berpengaruh Terhadap pemberian ASI secara Eksklusif pada ibu yang melahirkan anak pertama. JTIK 3(2), 106-214.

Sringati, S., (2016). Hubungan Antara Tingkat Motivasi dan Tingkat Pengetahuan Ibu dalam Memberikan ASI secara Eksklusif di wilayah desa Jono'oge. JKT Vol.2 No.1. Diunduh dari: http://jurnal.untad.ac.id

Sriyono. (2015). Sastra Lisanyang Terdapat di Papua (Suku Moy). Vol.17 No.1.

Sunaryo. (2016). Asuhan Keperawatan Gerontik. Yogyakarta: Salemba Medika.

Suprihatin, E. (2018). Gambaran Pengetahuan (Kader Posyandu) Tentang Asi Eksklusif Di Desa Tegalombo, Puskesmas Kalijambe Sragen Jawa Tengah. Universitas Muhammadiyah Yogyakarta.

Tanoro, P. (2007). Analisis Kesulitan (Segi Psikologis) Usia Dewasa Awal Dalam Mempelajari Bahasa Mandarin. Bina Nusantara. Diunduh dari: http://library.binus.ac.id

Widanti, Y. A. (2013). Faktor Risiko, Angka Kejadian serta Efek Stunting Anak (18), 23-28. 